\title{
DEVELOPMENT OF EDUCATION IN THE TURKESTAN GENERAL PROVINCE AT THE END OF THE XIX - EARLY XX CENTURIES \\ (On the example of the Ferghana Valley)
}

\author{
Guldona Anvarbekovna Mamasolieva \\ Andizhan State University, Republic of Uzbekistan
}

Article DOI: https://doi.org/10.36713/epra9606

DOI No: 10.36713/epra9606

\begin{abstract}
The article describes the changes in education at the end of the first decade of the twentieth century and their causes associated with the spread of Jadidism and new method Muslim schools. The latter, combining a modernized system of studying Islam and elements of secular education, began to be perceived by the authorities as a threat to the spread of pan-Islamism and pan-Turkism in the region. But despite the changes, the main sources of literacy and education of the population of the Ferghana Valley were traditional educational institutions, that is, maktabs and madrasahs, which existed not at the expense of the state budget, but from public funds.
\end{abstract}

KEYWORDS. Maktab, karykhana, madrasah, mosque, education, otin oyi, waqf, state, calligraphy, khujra, mudarris, mutavaliy, mullah, mufti, qaziy, usuli jadid, panislamism, panturkism.

\section{INTRODUCTION}

In the second half of the nineteenth - early twentieth centuries. traditional schools functioned on the territory of Turkestan - maktabs, kar-khana and madrasahs. There were many of them, and basically they were centers of education, providing primary, secondary and, in part, higher education. The Turkestan governor-general Mishchenko pointed out that a dense network of maktabs and madrasahs covered the entire territory of the region [1].

In the Ferghana Valley, as in all of Central Asia, traditional schools appeared with the spread of the Islamic religion here. They were in all cities and villages. In maktabs, girls and boys were taught separately. Boys studied in maktabs at the mosque, madrassas and karykhans, and girls studied with "otin oyi", that is, with teachers.

\section{METHODS}

Maktabs for girls were located in the house of otin oyi or in the house of some rich person who had girls of school age. Girls were trained in approximately the same program as boys, but there were some differences. In women's maktabs, the works of Tajik and Turkic poets and writers were studied more, instead of the texts of the Koran. Their other originality was that in these schools girls were taught women's duties at home and behavior in society. In rural areas, there were very few such schools, unlike cities.

\section{RESULTS AND DISCUSSIONS}

Maktabs were not maintained at the expense of the state treasury, since they were opened not by the state, but by the public. Teachers received payment for their education from the parents of students or from public funds, that is, from waqf funds.

According to the ancient norms of Shariah, a certain tuition fee was not established, and teaching children to read and write was considered a charitable deed [2].

The number of students in rural maktabs at the mosque reached 10-20, and in urban - up to 50-60 people. In the Fergana region, there were 1143 such maktabs, there were still kar-khans - 312 and madrasas - 159 [3].

Classes were held from sunrise to $4-5$ o'clock in the afternoon, except for Fridays and public holidays. There was a change twice a day. In the summer, the students went on vacation for two months. Classical maktabs did not have a classroom system, as classes were conducted individually. Pupils learned to write only when they fully learned to read [4]. 


\title{
SJIF Impact Factor 2021: 8.013| ISI I.F.Value:1.241| Journal DOI: 10.36713/epra2016 ISSN: 2455-7838(Online) \\ EPRA International Journal of Research and Development (IJRD)
}

\author{
Volume: 7 | Issue: 2 | February 2022
}

- Peer Reviewed Journal

The quality of education largely depended on the requirements of the founders and trustees of the educational institution, as well as on the professionalism of teachers. Muslim maktabs instilled in their students one good side outward orderliness, accompanied by modesty and respect. Another good side of the Muslim maktab was that it did not destroy family rules and traditions in students, did not instill in them new habits and needs, and thus did not tear children away from the everyday environment, as a result of which those who did not complete the course in maktab returned home with unperverted ideas. about life and calmly accepted for personal labor (agriculture, trade, handicraft), according to the living conditions of their own family [5].

The children of the poor completed their education in primary schools. Children from wealthy families continued to study for another 8 years. After graduation, some of the graduates used their knowledge in trade matters, some made calligraphy their profession, and the most capable entered the madrasah.

Those who graduated from this school had the right to continue their studies in the madrasah - the highest confessional school in the Muslim East.

The second stage of education was madrasah, or secondary or higher schools, which, as a rule, existed only in cities and large villages. The word "madrasah" (madrasah) in Arabic means "place for learning", "school" [6].

Madrasahs, in terms of construction and material support, were divided into khan, eshan and private, and due to the size of the waqf property and the number of hujras - into large, medium, small and mosque madrasahs. The maintenance of the buildings of such madrasas and the payment to teachers (mudarris - in Arabic "teacher") were carried out from the income of donated property - waqfs. Supervision of the economy was carried out by special people - mutavaliy.

The curriculum of the madrasah included the study of Arabic grammar, theological and legal literature, as well as books on metaphysics, cosmography, astrology, geography, history, medicine and mathematics.

The entire course of study in the madrasah lasted 10 years. Its graduates were mainly ministers of mosques and teachers (mullahs) of maktabs. But among them, the most capable and punchy occupied the position of mudarris teacher of madrasah, qaziy - judge-interpreter of Muslim law and mufti - the highest Muslim cleric who had the right to make decisions on religious and religious-legal issues. Those who wanted to receive a more complete theological education went to Turkey, Egypt or India [7].

Along with Muslim maktabs, Russian-native schools operated in parallel throughout the Turkestan region. Back in 1868, the first Turkestan Governor-General Kaufman proposed to take as the basis for raising children not religious difference, but the same rules, with the help of which both Orthodox and Muslims can be made equal useful citizens of Russia [8]. Thus, the task of public education in the region was defined. A special commission appointed in 1870 to discuss the issue of organizing an educational unit in the region, guided by the instructions of the chief commander of the region, expressed this idea in detail as follows: "The main provision of the task of public education in the region should be its development in the direction of Russian interests, which mainly in the development of the economic side of the life of the non-Russian population, its citizenship and the solidarity of its aspirations with the foundations of Russian state life, and the religious convictions of the natives must remain without any encroachment [9].

Governor-General Kaufman, for this purpose, chose the tactics of "ignoring" the traditional Muslim school (maktabs and madrasas) in the expectation that it would not withstand competition with the "more progressive" Russian school. However, M. G. Chernyaev, who replaced Kaufman, launched an offensive against the Islamic school, proposing to introduce the Russian language and other subjects into the program of the new madrasah.

N. O. von Rosenbach, who took over the post of the chief head of the Turkestan region in 1884, considered it necessary to exercise great caution in relation to religious schools. As an alternative to them, he proposed the idea of Russian-native schools. The Muslim schools themselves were nominally placed under the control of the administration. But the hopes of the Russian government were not justified, since the old Muslim school and Islam in general turned out to be much stronger than they expected. In remote rural areas, children usually studied in elementary Muslim maktabs, less often in madrasas. The tsarist government periodically tried to take steps to block the opening of new Muslim schools. However, despite all the restrictions, Muslim schools opened everywhere in the region. In the Fergana region in 1892 there were 120, and in 1911 - 204 madrasas, which indicated a doubling of the number of madrasahs after joining Russia. In remote areas, maktabs often functioned "illegally", i.e. without the written permission of the authorities, and therefore, such establishments were not amenable to accurate accounting [10].

Russian policy towards traditional Muslim education in Central Asia from 1876 to 1907. changed drastically. If in 1876 it seemed that "Russian influence in the East presented an important and lofty task to break the mental fetters of Mohammedanism and introduce the natives to the life of mankind"[11], then in 1907 the Muslim school was compared with the ancient Russian Christian one, and the course of the madrasah was recognized as "very serious, considering the real needs of the people's life" and subject not to a radical breakdown, but to a gradual and careful evolution in the sense of "streamlining the education system and updating the knowledge itself in such sciences that do not concern religious belief [12]. For this reason, the Russian authorities in the Turkestan region, primarily in remote rural areas, taking into account the confessional situation in the newly conquered lands, did not take steps to spread Orthodoxy there. The activities of Orthodox missionaries in Central Asia were banned.

Although the Muslim education system covered a large part of the population, and each child received certain 


\section{SJIF Impact Factor 2021: 8.013| ISI I.F.Value:1.241| Journal DOI: 10.36713/epra2016 ISSN: 2455-7838(Online) \\ EPRA International Journal of Research and Development (IJRD) \\ Volume: 7 | Issue: 2 | February 2022 \\ - Peer Reviewed Journal}

skills and knowledge, in general, the literacy rate in rural areas remained very low. Since the main population of the villages consisted of farmers who were not able to create conditions for their children to study because of the constant agricultural work, where children played an important role.

At the end of the nineteenth century. in Turkestan, new method schools began to emerge - "usuli zhadid". The patrons of these schools were the Jadids - a group of enlightened Muslims of Turkestan who dreamed of reviving the national culture and political independence of their peoples, introducing them to modern life, to the achievements of world civilization and progress. New method schools appeared somewhat later than Russian-native schools, in the 1990s. nineteenth century The first new method school in the Ferghana Valley opened in 1897 at a cotton gin in the vicinity of Andizhan. Then the same schools began to open in other cities and villages throughout the valley. In 1898, in Kokand Salahiddin domla (teacher), in Tashkent - Mannon-kari, in Andijan - Shamsutdin domla, Jadid schools were opened.

The number of Jadid schools grew rapidly. According to official data of 1908, there were 30 Jadid schools in the Turkestan region, in which 1300 students studied, by 1911 their number increased to 63 with 4106 students. The number of schools in reality was much greater, the tsarist government was not able to keep records of schools opened by private individuals. The main reason for the increase in new method schools was the economic factor: as a result of the development of industry and trade in Turkestan, especially cotton growing, the emergence of a new layer of society accelerated - wealthy entrepreneurs capable of conducting trading operations involving thousands, sometimes even millions of monetary units, having profitable shares, valuable paper and high-yield land. As a result, new economic relations appear and the need for competent personnel accountants, translators, clerks, etc. For this reason, most of the new schools were opened in the territories of cotton mills and houses of large merchants. For example, the first Jadid school in Andijan, as noted above, was opened in the building of the Sultanmuradbay cotton gin plant with the personal money of Abdugafur Amin. In the surrounding villages of Andijan, there were 15 new method schools, 12 of which were opened in the homes of rich people, 2 in the mosque building and 1 in a special building [13].

The following tasks were set for the new method schools: 1) to provide the younger generation with the knowledge necessary in modern conditions; 2) be guided by modern teaching methods different from the old-method schools. One of the positive methods of these schools was the transition to lesson-class teaching. In the lessons, especially history, visual aids were used: that is, modern maps of the world, globes, etc. For the learning process, the cleanliness and illumination of classes, sitting at desks, and changes between lessons were of great importance. New method schools were also distinguished by the fact that in the first half of the day they studied subjects of religious content, and the second - secular sciences (that is, civil).
At the end of the first decade of the 20th century, the Turkestan administration was forced to pay the most serious attention and reconsider its assessment of traditional maktabs and madrasahs. This happened precisely in connection with the spread of Jadidism and new method Muslim schools. The latter, combining a modernized system of studying Islam and elements of secular education, began to be perceived by the authorities as a threat to the spread of panIslamism and pan-Turkism in the region. The reaction to this was the measures taken by the regional authorities (not officially supported by St. programs and textbooks from the authorities. All this was supposed to put the new method maktabs and madrasas under the control of the Russian administration.

\section{CONCLUSION}

In conclusion, first of all, it can be noted that the main sources of literacy and education of the population of the Fergana Valley were traditional educational institutions, that is, maktabs and madrasahs, which existed not at the expense of the state budget, but from public funds. The purpose of their curriculum was to educate students from a real intelligent person who possessed such high moral qualities as prudence and modesty, especially inherent in the eastern peoples.

\section{REFERENCES}

1. Ardashirov A. To the question of the role of new method maktabs. Account Andijan State Pedagogical Institute. T.6. 1957.- P.137.

2. Bobrovnikov N.A. Russian-native schools, mektebs and madrasahs in Central Asia // Journal of the Ministry of Public Education. - 1913. No. 7.-p.54-55.

3. Kerensky O.M. madrasah of the Turkestan region. - St. Petersburg, 1893. - P.3 .; Central State Archive of the Republic of Uzbekistan, F.I.-47, op.1, file No. 333a, l.10.

4. Ostroumov N.P. Muslim maktabs and Russian-native schools in the Turkestan region. - Journal of the Ministry of Public Education. -1906, February. St. Petersburg "Senate Printing House".-p.143.

5. Ostroumov N.P. Madrasas in the Turkestan region // Journal of the Ministry of Public Education. 1907. Part 7, January. Section 3. p.28,20,31.

6. Tohir kakhkhor. Hur Turkiston uchun.// "Turkiston" gazetasi, 1992, February.

7. Qur'oni Karim. -T.: Chulpon, 1992. - p.64.

8. Central Asia within the Russian Empire. Rep. ed. S.N.Abashin, D.Yu.Arapov, N.E. Bekmakhanov.-M.: "New Literary Review", 2008. P.160.

9. National Archive of Uzbekistan, F.I.1, op. 31, d. No. 540, l. 141.

10. National Archive of Uzbekistan, F.I.1, op.11, file No. 1832 (a), l.1.

11. National Archive of Uzbekistan, F.I.-47, op.1, file No. 333, l.16.

12. National Archive of Uzbekistan, F.I.-2412, op. 1, d. No. 365, l. 39.

13. National Archive of Uzbekistan, F.I.-47, op.1, file No. 995, l. 230 . 